\title{
Molecular insights into the taxonomy of Hypanis (Bivalvia, Cardiidae, Lymnocardiinae) in the Black Sea lagoons
}

\author{
Luis Popa $\cdot$ Oana Popa $\cdot$ Elena Iorgu $\cdot$ \\ Beatrice Kelemen · Dumitru Murariu
}

Received: 21 October 2010 / Revised: 23 March 2011 / Accepted: 24 March 2011 / Published online: 8 April 2011

(C) Springer-Verlag and AWI 2011

\begin{abstract}
In this study, we used data from morphology and three DNA markers to assess the taxonomic status of the putative bivalve species Hypanis colorata and Hypanis angusticostata in a Black Sea lagoon, the Razelm Lake in Romania. The morphological data (the shape of shell ribs and the multivariate analysis of morphometric variance of three variables constructed as the ratios between the main dimensions of the shell) confirmed that the two analyzed species are distinct morphological entities. Three molecular markers, one from the nuclear genome (18S rRNA) and two from the mitochondrial genome (16S rRNA and COI), showed extremely reduced sequence divergence $(0-0.1 \%)$ between the two putative species. Based on these results, we suggest that $H$. angusticostata and $H$. colorata are morphotypes of a single species.
\end{abstract}

Keywords Monodacna colorata $\cdot$ Monodacna angusticostata $\cdot$ Genetic distance $\cdot$ Molecular markers

Communicated by H.-D. Franke.

L. Popa and O. Popa contributed equally to this work.

Electronic supplementary material The online version of this article (doi:10.1007/s10152-011-0256-1) contains supplementary material, which is available to authorized users.

L. Popa $(\bowtie) \cdot$ O. Popa $\cdot$ E. Iorgu $\cdot$ D. Murariu

Grigore Antipa National Museum of Natural History,

Sos. Kiseleff Nr. 1, 011341 Bucharest, Romania

e-mail: popaluis@antipa.ro; popa_luis@yahoo.com

B. Kelemen

Babes-Bolyai University, Molecular Biology Center,

42 Treboniu Laurian Street, 400271 Cluj-Napoca, Romania

\section{Introduction}

The bivalve subfamily Lymnocardiinae in the family Cardiidae includes several fossil genera and two extant genera, Hypanis and Didacna. In the former genus, two subgenera have been described, Monodacna and Adacna. The subgenus Monodacna comprises about 20 living species and/or subspecies distributed in the Black, Azov, and Caspian Seas and the connected brackish lakes (Nabozhenko 2005). The literature on these species is scarce, and the diagnostic criteria used in species identification include only a small number of conchological and anatomical features with a great plasticity that leads to confusions and uncertainties (Borcea 1926; Munasypova-Motyash 2006a, b).

Borcea (1926) made the first extensive study on the Lymnocardiinae of the Black Sea lagoons and noticed the presence of two species of Hypanis in the subgenus Monodacna, Hypanis pontica (Eichwald, 1838) (presented as Monodacna pseudocardium), and Hypanis colorata (Eichwald, 1829) (presented as Monodacna colorata). He described four varieties of Hypanis colorata, namely $H$. colorata var. ialpugensis, $H$. colorata var. angusticostata, $H$. colorata var. razelmiana, and $H$. colorata var. lucida. Thirty years later Zhadin (1952) considered that in the USSR Fauna there were three species in the genus Hypanis (subgenus Monodacna): H. pontica (named M. pontica), $H$. colorata (named M. colorata), and H. edentula (Pallas, 1771) (named M. edentula syn. M. caspia (Eichwald, 1829)).

In Romania, Grossu (1962, 1973), Tudorancea (1972), Negrea and Negrea (1975), and Sarkany-Kiss (1995) identified only two Hypanis (subgenus Monodacna) species: $H$. pontica (M. pontica) and H. colorata (M. colorata). In a monography of the Black and Azov Seas, Scarlato and 
Starobogatov (1972) listed five species of this subgenus: H. (M.) pontica, H. (M.) colorata, H. (M.) caspia, H. (M.) angusticostata (Borcea, 1926), and H. (M.) ialpugensis (Borcea, 1926). Munasypova-Motyash (2006a, b) studied some anatomical features of the soft body and noticed the presence of three species of the subgenus Monodacna in Ukraine, $H$. angusticostata, $H$. colorata, and $H$. pontica.

In the present work, we studied the taxonomic status of the putative species Hypanis colorata and Hypanis angusticostata in the Razelm-Golovita Lake system in Romania. First, we examined how different these two putative species are from a morphological point of view, using a multivariate morphometric analysis. Then, we analyzed three molecular markers (18S rRNA, 16S rRNA, and COI) in order to see whether morphometric and genetic findings are in agreement. We also compared the genetic divergence between these two putative species with that between other congeneric species belonging to the family Cardiidae, using DNA sequences available in GenBank.

\section{Materials and methods}

Sample collection

Several hundred specimens of Hypanis were collected with a bottom dredge from the Razelm-Golovita Lake Complex $\left(44^{\circ} 19^{\prime} 23.56^{\prime \prime}-44^{\circ} 58^{\prime} 55.89^{\prime \prime} \mathrm{N} ; 28^{\circ} 47^{\prime} 11.47^{\prime \prime}-29^{\circ} 06^{\prime} 30\right.$. $53^{\prime \prime}$ E) in July 2007, July 2009, and August 2009, at a depth of 2-3 m. Upon collection, the samples were preserved in 96\% ethanol and transported to the laboratory for further processing. Morphological identification of the collected individuals was performed according to the shape of the ribs (higher or more flattened), the density of the ribs, the dentition of the cardinal platform, and the thickness of the valves according to Scarlato and Starobogatov (1972) and Munasypova-Motyash (2006a, b). The specimens analyzed were deposited in the collections of the "Grigore Antipa" National Museum of Natural History (Bucharest, Romania).

\section{Morphometric analysis}

The following three morphometric variables were measured in 114 specimens of $H$. colorata and $H$. angusticostata: shell length (SL: the maximum antero-posterior dimension of the shell), shell width (SW: the maximum left-right dimension with both valves appressed), and shell height ( $\mathrm{SH}$ : the maximum dorsal-ventral dimension of the shell measured perpendicular to the length). Bivalves were measured with a digital caliper, to the nearest $0.01 \mathrm{~mm}$. In order to maximize the correct identification of the specimens, all the analyzed individuals had a shell length larger than $20 \mathrm{~mm}$. The measured shell length (SL), shell width
(SW), and shell height (SH) were used to compute the SW/ $\mathrm{SL}, \mathrm{SH} / \mathrm{SL}$, and SW/SH ratios. A MANOVA analysis was performed with the species designation as independent variables and the three mentioned ratios as dependent variables, using the software package PAST (Hammer et al. 2001). A discriminant analysis/Hotelling test was performed using the same software package. A $P$ value of $\leq 0.05$ was considered statistically significant.

DNA isolation, amplification, and sequencing

DNA isolation was performed with the NucleoSpin ${ }^{\circledR}$ Tissue kit (Macherey-Nagel GmbH \& Co. KG, Düren, Germany), according to the producer's specifications. The primers used for the amplification of all three markers were designed with M13 tails to facilitate the DNA sequencing process. The sequences of the six primers were as follows (with the M13 tails in brackets): 16S rRNA, 16SF_M13f (5'-CACGACGTTGTAAAACGACcgcctgtttatcaaaaacat-3') and 16SR_M13r (5'-GGATAACAATTTCACACAGGcc gctctgaactcagatcacgt-3') (Palumbi et al. 1991); 18S rRNA, 18SF_M13f (5'-CACGACGTTGTAAAACGACccgaggc cccgtgattggaatgag-3') and 18SR_M13r (5'-GGATAACA ATTTCACACAGGctctgtcgccgcagtacgaatgcc- $3^{\prime}$ ) (Crease and Colbourne 1998); COI, CoxAF_M13f (5'-CACGACGTT GTAAAACGACcwaatcayaaagatattggaac-3') and CoxAR M13r (5'-GGATAACAATTTCACACAGGaatatawacttcw gggtgacc-3') (Colgan et al. 2003).

For all the markers, the amplification was performed in $25 \mu \mathrm{l}$ of a solution containing $10 \mathrm{mM}$ Tris $-\mathrm{HCl}(\mathrm{pH} 8.8$ at $25^{\circ} \mathrm{C}$ ), $50 \mathrm{mM} \mathrm{KCl}, 0.08 \%$ (v/v) Nonidet P40, $2.5 \mathrm{mM}$ $\mathrm{MgCl}_{2}$, each dNTP at $0.1 \mathrm{mM}$, each primer at $0.08 \mu \mathrm{M}$ $(0.1 \mu \mathrm{M}$ for the COI primers), 1 unit of Taq DNA polymerase (Fermentas UAB, Vilnius, Lithuania), and approximately $10 \mathrm{ng}$ of DNA template. The temperature profile of the polymerase chain reaction for the $16 \mathrm{~S}$ rRNA and $18 \mathrm{~S}$ rRNA markers consisted of initial denaturation at $94^{\circ} \mathrm{C}$ for $30 \mathrm{~s}$, followed by 2 cycles at $94^{\circ} \mathrm{C}$ for $30 \mathrm{~s}, 60^{\circ} \mathrm{C}$ for $45 \mathrm{~s}$, $72^{\circ} \mathrm{C}$ for $45 \mathrm{~s}$, followed by 5 cycles at $93^{\circ} \mathrm{C}$ for $30 \mathrm{~s}, 55^{\circ} \mathrm{C}$ for $45 \mathrm{~s}, 72^{\circ} \mathrm{C}$ for $45 \mathrm{~s}$, followed by 29 cycles at $93^{\circ} \mathrm{C}$ for $30 \mathrm{~s}, 50^{\circ} \mathrm{C}$ for $1 \mathrm{~min}, 72^{\circ} \mathrm{C}$ for $1 \mathrm{~min}$, and a final extension step performed at $72^{\circ}$ for 8 min. For the COI marker, the temperature profile of the amplification reaction consisted of initial denaturation at $94^{\circ} \mathrm{C}$ for $2 \mathrm{~min}$, followed by 5 cycles at $94^{\circ} \mathrm{C}$ for $30 \mathrm{~s}, 45^{\circ} \mathrm{C}$ for $30 \mathrm{~s}, 72^{\circ} \mathrm{C}$ for $30 \mathrm{~s}$, followed by 35 cycles at $94^{\circ} \mathrm{C}$ for $30 \mathrm{~s}, 54^{\circ} \mathrm{C}$ for $30 \mathrm{~s}, 72^{\circ} \mathrm{C}$ for $30 \mathrm{~s}$, and a final extension step performed at $72^{\circ}$ for $5 \mathrm{~min}$. The PCR products were separated on $1 \%$ agarose gel, and the fragments of interest were excised and extracted using the GeneJET ${ }^{\mathrm{TM}}$ Gel Extraction Kit (Fermentas UAB, Vilnius, Lithuania).

The sequencing reaction was performed on a LICOR 4300L system, with the DNA Cycle Sequencing Kit (Jenna 
Bioscience GmbH, Jena, Germany) with M13-labeled primers, according to manufacturer's specifications, on 9 samples for the COI marker, 30 samples for the 16S rRNA marker, and 14 samples for the 18S rRNA marker.

Sequences analysis

The COI, 16S rRNA, and 18S rRNA sequences were aligned using the ClustalX program (Larkin et al. 2007). Uncorrected genetic distances $(p)$ were estimated for all pairwise comparisons as the proportion of nucleotide sites that are different, as implemented in MEGA version 4 (Tamura et al. 2007). In order to asses the genetic distance among congeneric species as well as among individuals of the same species, we used 335 DNA sequences from the family Cardiidae available in GenBank from 11 genera for the 16S rRNA, and 3 genera for both 18S rRNA and COI. The list of genera, species, and accession numbers is shown in Online Resource 1.

\section{Results}

Morphometric analysis

A number of 114 bivalve specimens of the subfamily Lymnocardiinae were collected and measured. Among these specimens with more than $20 \mathrm{~mm}$ in length, we identified 79 specimens of Hypanis colorata and 35 specimens of Hypanis angusticostata. The multivariate normality of the computed ratios was checked by Mardia's kurtosis test $\left(p_{\text {normal }}=0.8935\right)$ and with the Doornik and Hansen omnibus test $\left(p_{\text {normal }}=0.9666\right)$. The assumption of homogeneity of variance covariance matrices was tested with Box's M test $\left(p_{\text {equal }}=0.07\right)$. The MANOVA analysis rejected the hypothesis of equality of the means for the two designated species, both in Wilks's lambda test $\left(p_{\text {same }}=8.8 \mathrm{e}-09\right)$ and the Pillai trace test $\left(p_{\text {same }}=3.8 \mathrm{e}-09\right)$. The same result was obtained with Hotelling's t 2 test $\left(p_{\text {same }}=3.2 \mathrm{e}-05\right)$. A percentage of $68.42 \%$ of the samples was correctly classified with the discriminant analysis.

Genetic analysis

We sequenced a COI fragment of approximately $600 \mathrm{bp}$ from 5 specimens of $H$. colorata and 4 specimens of H. angusticostata. Among these nine COI sequences, we identified only two haplotypes differing by one nucleotide position, which does not affect the amino acid sequence of the protein. The two haplotypes were present in both species (accession numbers HQ420301-HQ420304). We sequenced also a 16S rRNA fragment of approximately
Table 1 Genetic markers analyzed in the two Hypanis species

\begin{tabular}{|c|c|c|c|}
\hline & \multicolumn{3}{|c|}{ Nseq/hap/shared } \\
\hline & COI & $16 \mathrm{~S}$ & $18 \mathrm{~S}$ \\
\hline H. colorata & $5 / 2 /$ yes & 24/2/yes & 11/1/yes \\
\hline $\begin{array}{l}\text { Accession } \\
\text { numbers }\end{array}$ & $\begin{array}{l}\text { HQ420301, } \\
\text { HQ420303 }\end{array}$ & $\begin{array}{l}\text { HQ420295, } \\
\text { HQ420298 }\end{array}$ & HQ420299 \\
\hline H. angusticostata & $4 / 2 /$ yes & 6/2/yes & 3/1/yes \\
\hline $\begin{array}{l}\text { Accession } \\
\text { numbers }\end{array}$ & $\begin{array}{l}\text { HQ420302, } \\
\text { HQ420304 }\end{array}$ & $\begin{array}{l}\text { HQ420296, } \\
\text { HQ420297 }\end{array}$ & HQ420300 \\
\hline
\end{tabular}

Nseq number of analyzed sequences, Hap number of observed haplotypes, Shared presence/absence of the observed haplotypes in both species

$430 \mathrm{bp}$ from 24 specimens of $H$. colorata and 6 specimens of $H$. angusticostata. Among the 30 obtained sequences, we identified two haplotypes differing by one nucleotide position, and the two haplotypes were present in both species (accession numbers HQ420295-HQ420298). Finally, we sequenced an 18S rRNA fragment of approximately $350 \mathrm{bp}$ from 11 specimens of $H$. colorata and 3 specimens of $H$. angusticostata. The 14 sequences belonged to a single haplotype (accession numbers HQ420299-HQ420300) (Table 1).

\section{Distance analysis}

The uncorrected $p$-distances calculated for all three markers for the two putative species of the genus Hypanis were compared with the same distances calculated between species in other genera of the family Cardiidae, available in GenBank. In all cases, the distance between our Hypanis putative species was at least one order of magnitude lower than that between other congeneric species (Table 2). Moreover, the genetic distance between our Hypanis putative species was closer to the range observed when we calculated the intraspecific distances for other species of the family Cardiidae (Table 3).

\section{Discussion}

The systematics of the bivalve genus Hypanis, subgenus Monodacna, is controversial. While some authors have recognized only two species in the subgenus, others have identified up to five (Yurishinets et al. 2002). However, the delimitation of these species has been always based only on morphological characters. We show here that the putative species $H$. colorata and $H$. angusticostata lack the genetic differentiation seen in other bivalve species of the family Cardiidae. 
Table 2 Mean intrageneric (interspecific) $p$-distance for the three investigated markers

\begin{tabular}{|c|c|c|}
\hline Genus & $p$-distance & SE \\
\hline \multicolumn{3}{|l|}{ COI } \\
\hline Cerastoderma & 0.179 & 0.016 \\
\hline Fragum & 0.228 & 0.011 \\
\hline Lunulicardia & 0.146 & 0.014 \\
\hline Hypanis & 0.001 & 0.001 \\
\hline \multicolumn{3}{|l|}{ 16S rRNA } \\
\hline Acanthocardia & 0.035 & 0.009 \\
\hline Americardia & 0.139 & 0.016 \\
\hline Cerastoderma & 0.121 & 0.015 \\
\hline Ctenocardia & 0.259 & 0.014 \\
\hline Fragum & 0.14 & 0.011 \\
\hline Fulvia & 0.188 & 0.03 \\
\hline Lunulicardia & 0.021 & 0.007 \\
\hline Hypanis & 0.001 & 0.001 \\
\hline Nemocardium & 0.147 & 0.016 \\
\hline Papyridea & 0.236 & 0.02 \\
\hline Parvicardium & 0.179 & 0.017 \\
\hline Trigoniocardia & 0.16 & 0.016 \\
\hline \multicolumn{3}{|l|}{ 18S rRNA } \\
\hline Fragum & 0.002 & 0.001 \\
\hline Hypanis & $\mathbf{0}$ & $\mathbf{0}$ \\
\hline Vasticardium & 0.004 & 0.001 \\
\hline
\end{tabular}

$S E$ standard error

Are the two discussed putative species morphologically distinct?

The morphological characters used by different authors show merely subtle variation between our putative species (Borcea 1926; Grossu 1962; Munasypova-Motyash 2006a, b). The only character used to distinguish them is the shape of the ribs, with sharp ribs in $H$. angusticostata and flat ribs in $H$. colorata. This character could be an adaptation to different life habits of the two putative species. According to Munasypova-Motyash (2006b), H. angusticostata burrows in surface-near $(1-3 \mathrm{~cm})$ sediment layers, while $H$. colorata lays flat on the surface of the same sediment type. According to Savazzi and Sälgeback (2004), the sharp ribs strengthen the shell under sediment pressure and provide a more intimate contact with, and thus a better anchoring in, the sediment. On the other hand, flat ribs may ensure an even weight distribution preventing sinking for shells living on the sediment surface. Apart from analyzing the shape of the ribs, we performed a multivariate analysis of the two putative species, using as variables the ratios between the main dimensions of the shells (width, length, height). We observed significant differences between the two putative
Table 3 Mean intraspecific $p$-distance for the three investigated markers

\begin{tabular}{lll}
\hline Species & $p$-distance & SE \\
\hline COI & & \\
Cerastoderma edule & 0.021 & 0.002 \\
Cerastoderma glaucum & 0.032 & 0.004 \\
Corculum cardissa & 0.021 & 0.003 \\
Fragum fragum & 0.018 & 0.003 \\
Fragum loochooanum & 0.03 & 0.004 \\
Fragum mundum & 0.038 & 0.005 \\
Fragum unedo & 0.07 & 0.007 \\
16S rRNA & & \\
Cerastoderma edule & 0.026 & 0.004 \\
Cerastoderma glaucum & 0.023 & 0.006 \\
Corculum cardissa & 0 & 0 \\
Fragum fragum & 0.01 & 0.003 \\
Fragum loochooanum & 0.011 & 0.003 \\
Fragum mundum & 0.005 & 0.002 \\
Fragum unedo & 0 & 0 \\
18S rRNA & & 0 \\
Cerastoderma edule & 0 & \\
\hline SE & & \\
\hline
\end{tabular}

$S E$ standard error

species. Since the metrics used in the analysis were not used for the initial identification, we consider these findings an additional support for the opinion that $H$. colorata and $H$. angusticostata represent two distinct morphological entities (putative species). Only $68.42 \%$ of the analyzed individuals were correctly classified with the discriminant analysis, and this could be caused by the existence of hybrid forms between the two putative species. In fact, Borcea (1926) recognized the existence of hybrid forms between the variaties of $H$. colorata that he described.

How different are the two putative species from a genetic point of view?

To answer this question, we chose three different markers, one from the nuclear genome (18S rRNA) and two from the mitochondrial genome (16S rRNA and COI). All these markers have been intensively used in decrypting molecular phylogenies within the bivalve mollusks, while some authors used them specifically to distinguish between different animal species. Recently, Guarniero et al. (2010) used all the above markers (and in addition the 12S rRNA sequence) to distinguish between two bivalve sibling species. In our samples, the observed variation was represented by one nucleotide position (out of several hundred base pairs) in both COI and 16S rRNA markers, while the $18 \mathrm{~S}$ rRNA marker showed no variation at all. When variation 
was present, the two observed haplotypes were present in both species.

How much genetic variation would we expect to find between two species in the same genus?

To answer this question, we analyzed 335 DNA sequences belonging to congeneric species of the family Cardiidae available in GenBank, for all the markers used in this study. Our results show that for the $16 \mathrm{~S}$ rRNA and COI markers, the mean congeneric $p$-distance was 0.165 . This was not different from the value reported by Mikkelsen et al. (2007), who also studied the genetic distance between congeneric bivalve species in the same genera. The $p$-distance between our two Hypanis species was 0.001 , i.e., two orders of magnitude lower than the above values. For the $18 \mathrm{~S}$ rRNA marker, the intra-generic mean $p$-distance was calculated to be 0.002 in the genus Fragum, and 0.004 in the genus Vasticardium, while the same distance between our Hypanis species was zero. Livi et al. (2006) analyzed 82 pairs of congeneric bivalve species and found 8 pairs of species also exhibiting no difference in the 18S rRNA sequence. To gain new insights from these genetic distances calculations, we analyzed the intraspecific genetic variation for species in the family Cardiidae, where data were available. For the $16 \mathrm{~S}$ rRNA, the average $p$-distance was 0.01 , while for the COI marker, the average $p$-distance was 0.03 . As these distances are still one order of magnitude higher than those between our species, it is obvious that the genetic distances between $H$. colorata and $H$. angusticostata match rather with the intraspecific than with the congeneric (interspecific) range of values. However, we have to keep in mind that the observed genetic divergence is positively correlated with the age of the species analyzed, with some markers (COI, for example) not being able to differentiate species that arose less than one million years ago (Avise 1994).

What is the significance of the reduced genetic differentiation between $H$. colorata and $H$. angusticostata?

Two scenarios could explain the mismatch between the morphological and the molecular data. The first scenario is that the two putative species are actually morphotypes of the same species, showing morphological adaptations to different substrates. In fact, Borcea (1926) described $H$. angusticostata from Razelm Lake as a variety of $H$. colorata, and only later $H$. angusticostata was given species rank by Scarlato and Starobogatov (1972). The second scenario would be that $H$. colorata and $H$. angusticostata represent very young species that do not yet exhibit a noticeable level of genetic differentiation for the studied markers. However, we also sequenced a $379 \mathrm{bp}$ fragment of the nuclear ITS2 region (data not shown) and found only one haplotype shared between the two putative species. The ITS2 region is known to have a higher mutation rate than the other markers used in this paper and thus should show variation even in young species. The absence of this kind of variation in our samples led us to reject the second scenario. Further work using fast-evolving DNA markers (microsatellite DNA) should be directed to the genetic analysis of $H$. colorata and $H$. angusticostata in the Eastern Black Sea and Caspian Sea, where the two species have been also noticed. However, the arguments presented above and the fact that the Black Sea lagoons represent the terra typica of both species, we have good reasons to suggest that $H$. angusticostata and $H$. colorata are morphotypes of the same species.

Acknowledgments This study was supported by the Grant IDEI no. 265/01.10.2007 from the National University Research Council, allotted to D. Murariu. We thank Andrei Sárkány-Kiss for the help with the collection and identification of the material. We thank Melania Cristescu, Dan Cogalniceanu, Jan Johan ter Poorten, Ioan Sarbu, Miklos Szekeres, and two anonymous reviwers for useful comments on earlier versions of the manuscript.

\section{References}

Avise JC (1994) Molecular markers, natural history and evolution. Chapman and Hall, New York

Borcea I (1926) Quelques remarques sur les Adacnides et principalement sur les Adacnides des Lacs Razelm. Ann Sc Univ Iassy 13(3-4):449-485

Colgan DJ, Ponder WF, Beacham E, Macaranas JM (2003) Gastropod phylogeny based on six segments from four genes, representing coding or non-coding and mitochondrial or nuclear DNA. Moll Res 23:123-148

Crease TJ, Colbourne JK (1998) The unusually long small-subunit ribosomal RNA of the crustacean, Daphnia pulex: sequence and predicted secondary structure. J Mol Evol 46:307-313

Grossu AV (1962) Bivalvia-Fauna R.S.R. 3 (3): 1 - 426

Grossu AV (1973) Les Limnocardiides actuelles du Bassin PontoCaspique. Inf Soc Belgique de Malac 2(7-8):123-152

Guarniero I, Plazzi F, Bonfitto A, Rinaldi A, Trentini M, Passamonti M (2010) The bivalve mollusc Mactra corallina: genetic evidence of existing sibling species. J Mar Biol Assoc UK 90(3): 633-644

Hammer $\varnothing$, Harper DAT, Ryan PD (2001) PAST: paleontological statistics software package for education and data analysis. Palaeontol Electron 4(1):9

Larkin MA et al (2007) Clustal W and Clustal X version 2.0. Bioinformatics 23:2947-2948

Livi S, Cordisco C, Damiani C, Romanelli M, Crosetti D (2006) Identification of bivalve species at an early developmental stage through PCR-SSCP and sequence analysis of partial 18S rDNA. Mar Biol 149:1149-1161

Mikkelsen N, Schander C, Willassen E (2007) Local scale DNA barcoding of bivalves (Mollusca): a case study. Zool Scr 36(5):455-463

Munasypova-Motyash IA (2006a) Morphometrical characters of the shell of the bivalvial mollusks of the subfamily Limnocardiinae (Bivalvia, Cardiidae) and its significance in their taxonomy. Vestn Zool 40(6):521-527 (in Russian) 
Munasypova-Motyash IA (2006b) On the recent fauna of subfamily Limnocardiinae (Bivalvia, Cardiidae) in North-Western shore of Black Sea. Vestn Zool 40(1):41-48 (in Russian)

Nabozhenko MV (2005) Distribution of the genus Hypanis Pander in Ménétriés, 1832 (Bivalvia, Cardioidea: Limnocardiidae) in the Taganrogsky Gulf (The Sea of Azov). Ekol Morya 69:44-49 (in Russian)

Negrea S, Negrea A (1975) Ecology of gastropod and cladoceran populations of the Danube floodplain. Romanian Academy Publishing House, Bucharest (in Romanian)

Palumbi SR, Martin A, Romano S, McMillan WS, Stice S, Grabowski G (1991) The simple fool's guide to PCR. University of Hawaii, Honolulu, HI

Sarkany-Kiss A (1995) The Limnocardiidae Stoliczka 1870 species (Mollusca: Bivalvia) in the maritime region of the Danube Delta. In: Twelfth International Malacological Congress, pp 105-106
Savazzi E, Sälgeback J (2004) A comparison of morphological adaptations in the cardiid bivalves Cardium and Budmania. Paleontol Res 8:221-239

Scarlato OA, Starobogatov YI (1972) Opredeliteli Fauni Cernogo i Azovkogo Morei, vol T3. Kiev (in Russian)

Tamura K, Dudley J, Nei M, Kumar S (2007) MEGA 4: molecular evolutionary genetics analysis (MEGA) software version 4.0. Mol Biol Evol 24:1596-1599

Tudorancea C (1972) Studies on Unionidae populations from the Crapina-Jijila complex of pools (Danube zone liable to inundation). Hydrobiologia 39(4):527-561

Yurishinets VI, Korniushin AV, Mynasypova IS (2002) On recent Lymnocardiidae (Bivalvia: Cardioidea) in the fauna of Ukraine: unresolved problems. The Herald of Zhytomyr State Ivan Franko University 10:110-112 (in Ukrainian)

Zhadin V (1952) Molluscs of the fresh and brackish waters of the URSS. Academy of Sciences of the URSS, Moscow (in Russian) 